\title{
Structural Changes and Problems in the Rural Areas in Finland
}

\author{
RIITTA AUVINEN
}

Docent

Department of Social Policy

University of Helsinki

During the past decade Finnish society has been characterized by a strong structural change. In 1950 nearly one-half of the working population still earned their living from agriculture. In 1980 the corresponding share was only about one-tenth. On the whole, the structural change has benefited the economy of the country. There have also been some less beneficial side effects: the impact of the rapid development has been rather unfavorable, especially for the rural population.

A typical feature of the structural change has been rapid urbanization and migration resulting in the depopulation of large rural areas located in Central and Northern Finland as well as in North Karelia (Figure 1). The age structure of these areas is rapidly growing older, the economic situation has deteriorated, there have been greater difficulties in maintaining the services people need, and so on. All kind of problems accumulate.

\section{Age structure grows elder}

In the depopulated areas old age and disability to work are a part of the lives of many families. In $198013.2 \%$ of the population in the countryside had reached 65 years of age. The corresponding percentage in the cities was considerably smaller: $11.3 \%$. When the situation is compared with that of earlier years we notice that before the postwar "flight from the country", for example in 1950 , the percentages were 6.9 and 5.9 , respectively. In the countryside the population has grown older more rapidly than the population in the cities (Figure 2).

When the age structure of rural municipalities is studied more closely it can be observed that in many municipalities in Finland over $20 \%$ of the population is more than 65 years old; in 1978 this was the case in 32 of the 377 municipalities. In more than 170 municipalities over $15 \%$ of the population was 
Figure 1. The internal migration in $1960-1975$ as a percentage of net inmigration or net out-migration in the end of 1960 by provinces.

Provinces
$\begin{aligned} 1 & \text { Uusimaa } \\ 2 & \text { Turku \& Pori } \\ 3 & \text { Alland } \\ 4 & \text { Häme } \\ 5 & \text { Kymi } \\ 6 & \text { Mikkeli } \\ 7 & \text { Pohjois-Karjala } \\ 8 & \text { Kuopio } \\ 9 & \text { Keski-Suomi } \\ 10 & \text { Vaasa } \\ 11 & \text { Oulu } \\ 12 & \text { Lappi }\end{aligned}$

Provinces

Uusimaa

\& Pori

Aland

Häme

5 Kymi

6 Mikkeli

7 Pohjois-Karjala

8 Kuopio

9 Keski-Suomi

11 Oulu

12 Lappi

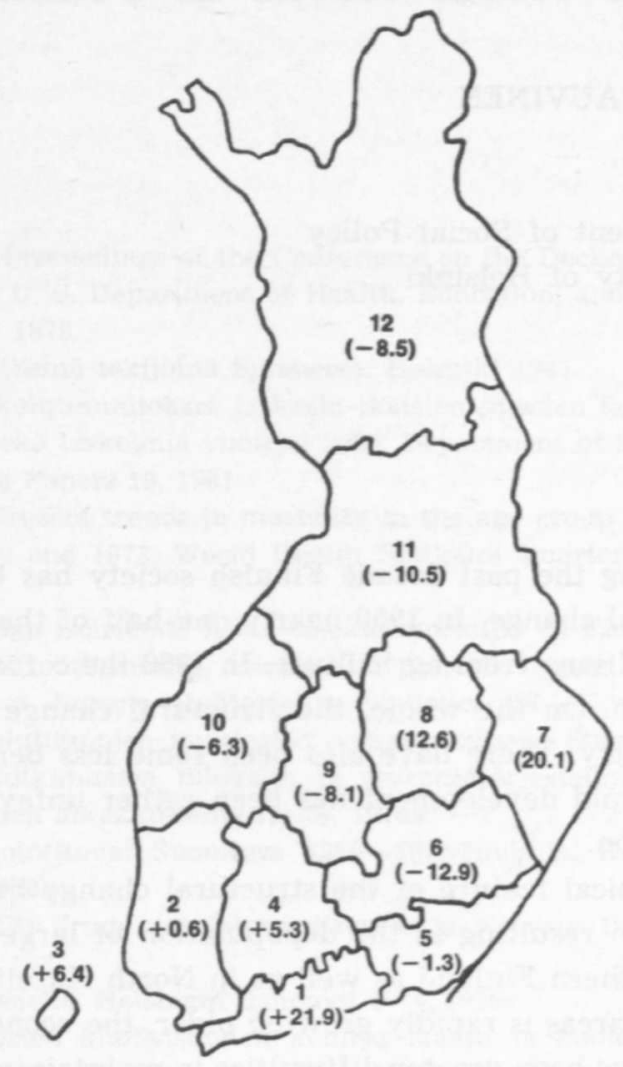

retired. In more than one half of the municipalities in the depopulated areas over $25 \%$ of the population retired during the late 1970's because of old age or work disability, and it is estimated that the number will continue to increase. With the increase in age, one's possibilities of earning one's living worsen. As the healthy and the professionally skilled moved away, only the old and weak remain.

The fact that the age structure is growing older can be seen very clearly especially within agriculture and forestry. In 1975 the average age of the farm enterpreneur was 46 years, while the average age of other enterpreneurs was 10 years lower (CSO 1978). According to a prognosis made by the Marketing Research Institute of the Pellervo Society and the Office of the Council of State (Honkanen et al. 1979) the average age of agricultural workers will slightly decrease over the next few years, and at the same time the regional differences will grow somewhat. The average age will increase in Southern Finland and decrease in Northern and Eastern Finland. 
Figure 2. The age structure in rural municipalities in Finland in $1950-1980$.

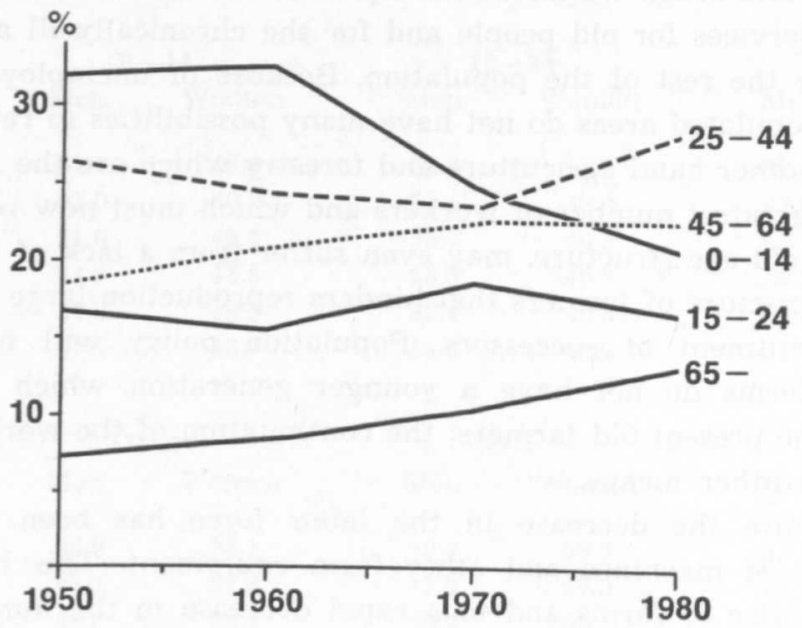

The average age of agricultural enterpreneurs is higher than that of the population in agriculture and forestry on the average. While 7 $\%$ of the population in agriculture and forestry has reached 65 years of age, the corresponding figure is $9 \%$ for the agricultural enterpreneurs. During the past few years the new pension systems have given elderly workers a chance to retire before the actual pension age. If the situation in the country as a whole is considered, the influence of these systems will obviously be rather small because it is estimated that there will be only a slight increase in the number of young farmers in the future.

In the depopulated areas where there are few young workers, both the private and the public economy will have to face problems differing from those in the areas of net immigration. Mental energy and other mental capital are being lost along with the outflux of the young, active population. The rate of increase in income will slow down. In addition, the continuation in depopulation from year to year - although the yearly rate would not be very considerable - steadily weakens the basic conditions of economic activity. Problems tend to pile up and accumulate. Internal migration in Finland has caused obvious geographical differences in development over the past decades.

\section{Decreasing labor force}

The demand for investment and consumption will decrease because of the smaller rate of income. In the depopulated areas the smaller population with its smaller income will have to pay a greater price in order to maintain 
existing services. The unfavorable age structure will be seen in the high price of health care and social welfare. Municipalities are forced to arrange the care of and other services for old people and for the chronically ill at the expense of services for the rest of the population. Because of unemployment, municipalities in depopulated areas do not have many possibilities to retain the population. On the other hand agriculture and forestry which are the industries that have lost the greatest number of workers and which must now rely on a labor force with an old age structure, may even suffer from a lack of workers. Still, it is the age structure of farmers that hinders reproduction large enough to ensure the recruitment of successors. Population policy will not help here, because the farms do not have a younger generation which can carry on the work of the present old farmers; the continuation of the work must be ensured through other means.

In agriculture the decrease in the labor force has been offset by the increasing use of machines and other farm equipment. This has led to the growth of the size of farms and to a rapid decrease in the number of farms. At the same time both farms and production areas have rapidly specialized. In the present situation it has been possible to raise the income of farmers only by raising productivity and above all by relying on the fact that from year by year a smaller group of farmers will be sharing the total income of agriculture. In spite of all this it has proved to be very difficult to bring the farmers' level of income to that of the rest of the population. In this, the agricultural policy has not been totally successful.

In the future it will not be possible for the agricultural population to switch over to other means of livelihood, and because of the wrong age structure it will obviously be difficult to find workers who could continue the work in agriculture. The strong decrease in the agricultural population could easily lead to a shortage of production even if the self-sufficiency of production would stay on the projected level. Especially in Eastern and Northern Finland it will be difficult to maintain the basic population if the number of farmers decreases from the present. The aim is to maintain the structure of the agricultural population and agriculture so that the size of the population working in agriculture would not go under 190,000 persons, even over the long run (Suokko 1981).

\section{Unbalanced sex structure}

The solution of Finland's rural population question is problematic not only because of the age structure of the rural population but also because of the sex structure of the population. Owing to the nature of the jobs and especially to the development of the service industries internal migration has brought young women from rural areas to the cities, which has meant an unbalanced sex structure of population both in rural and in urban areas. There are too many 
$\mathrm{Table} 1$. The sex structure of the rural population according to age in $1950-1978$.

\begin{tabular}{|c|c|c|c|c|c|c|}
\hline \multirow{2}{*}{ Year } & \multicolumn{2}{|c|}{$0-14$} & \multicolumn{2}{|c|}{$15-24$} & \multicolumn{2}{|c|}{$25-44$} \\
\hline & Men & Women & Men & Women & Men & Women \\
\hline 1950 & 51.0 & 49.0 & 52.6 & 47.4 & 48.8 & 51.2 \\
\hline 1960 & 51.0 & 49.0 & 51.1 & 48.9 & 49.6 & 50.4 \\
\hline 1970 & 51.0 & 49.0 & 53.7 & 46.3 & 52.1 & 47.9 \\
\hline 1975 & 51.2 & 48.8 & 53.8 & 46.2 & 53.1 & 46.9 \\
\hline 1978 & 51.2 & 48.8 & 53.4 & 46.6 & 53.4 & 46.6 \\
\hline 1980 & 51.2 & 48.7 & 53.0 & 46.9 & 53.4 & 46.6 \\
\hline \multirow{2}{*}{ Year } & \multicolumn{2}{|c|}{$45-64$} & \multicolumn{2}{|c|}{$65-$} & \multicolumn{2}{|c|}{ Total } \\
\hline & Men & Women & Men & Women & Men & Women \\
\hline 1950 & 46.9 & 53.1 & 40.5 & 59.5 & 49.2 & 50.8 \\
\hline 1960 & 47.2 & 52.8 & 41.0 & 59.0 & 49.7 & 50.3 \\
\hline 1970 & 46.6 & 53.4 & 40.9 & 59.1 & 49.9 & 50.1 \\
\hline 1975 & 47.5 & 52.5 & 40.5 & 59.5 & 50.0 & 50.0 \\
\hline 1978 & 48.2 & 51.8 & 39.7 & 60.3 & 50.0 & 50.0 \\
\hline 1980 & 48.6 & 51.4 & 39.1 & 60.9 & 49.1 & 50.9 \\
\hline
\end{tabular}

women in the cities and at the same time rural areas lack young housewives. It has become more difficult to find a spouse (Table 1).

The fact that the young female population moves from the countryside to the cities has special consequences for farmers wishing to form a family. At the moment there are about 30,000 young men in agriculture without a wife. And there will be less and less young women at or near the age of marriage in agriculture in the future.

In 1976, 124,000 agricultural workers were women and they gave birth to only 1,800 children. The northern and eastern rural areas of the country used to be areas with high birth rates and at the same time population reserves. Now the differences between the various parts of the country have evened out and the former Finnish population reserve in the countryside no longer exists. Especially in the farming areas where the birth rates used to be highest, the decrease in birth rates has been the most rapid. One explanation for this might be that rural housewives are better educated than their husbands. At any rate, as the result of internal migration the rural population has grown older and the urban population younger, and as a consequence the crude birth rates are higher in the cities than in the countryside. Today in agriculture there are 3-4 times more young men than women at the age when families are usually started. The fact that there are not enough housewives in the countryside in the future will also lead to a decrease in rural birth rates and obviously force us to re-estimate the possibilities of protecting this basic industry. 


\section{Lost political power}

Also the political alternatives in a democracy are dependent on the population structure and on the regional distribution of the population.

As the young healthy labor force has moved from the depopulated areas - i.e. Eastern and Northern Finland - to southern cities and industrial centers, eastern and northern municipalities have lost their political significance as shown by table 2 .

From 1962 up to the Parliamentary elections in 1979 the number of Parliamentary seats in the province of Uusimaa has increased from 17 to 26 . The electoral districts of Eastern and Northern Fin'and have each lost 1-2 seats in Parliament; North Karelia has lost three seats. The Parliamentary representation and at the same time the political power of industrial Finland has increased from 97 seats to 107 out of the 200 seats, i.e. to a majority (Hulkko 1980). Along with the population, political power has thus moved from agricultural Finland to industrial Finland and this fact naturally has influenced the contents and the formation of political goals, for example in regional policy.

In their regional political goals all political parties seem to have accepted the view that inhabitants must have equal possibilities to secure their living, get a job and obtain cultural and health services regardless of where they live.

$\mathrm{Tab}$ e 2. The number of inhabitants and the distribution of the seats of the members of Parliament in the electoral districts.

$\begin{array}{lcccc} & \text { Inhabitants } & \begin{array}{c}\text { Number of } \\ \text { Parliamentary } \\ \text { seats }\end{array} & \text { Inhabitants } & \begin{array}{c}\text { Number of } \\ \text { Parliamentary } \\ \text { seats }\end{array} \\ \text { Helsinki } & 1962 & 1962 & 1978 & 1978 \\ \text { Uusimaa } & 476436 & 20 & 484879 & 20 \\ \text { Turku and Pori, south } & 876399 & 17 & 1111067 & 26 \\ \text { Turku and Pori, north } & 665614 & 16 & 701176 & 17 \\ \text { Aland } & 21098 & 14 & & 13 \\ \text { Häme, south } & 592446 & 1 & 22542 & 1 \\ \text { Häme, north } & & 12 & 661107 & 15 \\ \text { Kymi } & 343136 & 15 & 345872 & 13 \\ \text { Mikkeli } & 232895 & 11 & 209375 & 9 \\ \text { Northern Karelia } & 202970 & 10 & 176825 & 7 \\ \text { Kuopio } & 269122 & 12 & 251600 & 11 \\ \text { Central Finland } & 247888 & 11 & 241793 & 10 \\ \text { Vaasa } & 445219 & 10 & 428122 & 10 \\ \text { Oulu } & 413794 & 18 & 413244 & 17 \\ \text { Lappi } & 212661 & 9 & 195365 & 8 \\ & & 200 & & 200\end{array}$


The balancing of the differences which exist in living conditions, the balancing of migration as well as the directing of the location of industry and services are also objectives. No party program, however, specifically gives demographic goals for regional policy. And as the demographic goals do not exist, there obviously are no demographic means given to reach such goals. Population together with capital are the primary elements of all productive activity.

In conclusion: the question is, will the age and sex structure of the rural population change even more in the future? The general development indicates that at least the age structure will continue to grow older. On the other hand systematical regional policy can retard this development. The increasing significance of agricultural means of livelihood and the switch of farms over towards a more enterprise-oriented basis are also facts which may lead to a decrease in the age of the farm population. On the other hand, the decrease in the rural population seems to be ending and rural areas are being seen as more and more desirable as a living environment for the future. The relative decrease in the attraction of the cities is mainly to be explained by the improving living conditions of the rural population. A significant observation is that in the middle of the 1970's migration turned into an exchange of population between urban areas. It can clearly be seen that there is also movement from the cities to the rural areas. The decrease of the rural population will obviously continue slightly, however, depending on people other than the population making their living in agriculture and forestry start to favor rural areas as a place to live in.

Changes in values have their own effect on new migration flows. The slowing down of, for example, economic growth and pollution have drawn more and more attention towards the quality of life and its meaning in the choice of a place to live in. But this is another question entirely.

\section{References}

Central Statistical Office. Population and Housing Census 1975. Households and families. Official Statistics of Finland VI C: 105, Vol. III. Helsinki 1978.

Hulkko, Jouko: Muuttoliikkeeseen vaikuttaminen. Muuttoliikesymposium, 1980 Turku. Härkänen, Seppo-Tauriainen, Juhani - Vihriälä, Vesa: Maa- ja metsätalouden työvoiman määrän ja rakenteen kehitys vuosina 1980, 1985 ja 1990. Valtioneuvoston kanslian julkaisuja 1979: 2 .

Suokko, Seppo: Maatalouspolitiikka 1980-luvulla suurten ratkaisujen edessä. PTT-katsaus 1,1981 , p. $1-7$. 